\title{
ELECTION MARKETING AND COMMUNICATION MANAGEMENT IN LOCAL PUBLIC SPHERE ${ }^{1}$
}

\begin{abstract}
The proposed paper is going to be an analysis of communication management during local elections campaigns in Poland in 2002, 2006, 2010, 2014, 2018. The 2002 was chosen as the starting point of the analysis because of the following facts: 1 ) those were the first direct local elections for mayors/ municipality heads; 2 ) the number of council members was reduced by law all of which heralded an interesting competition. The high turnover rate of candidates for councillors across different regions of Poland in 2002, 2006, 2010, 2014 and 2018 local government elections has been attributed in part to the volatility caused by greater media and public interest in council issues. The paper is based on: the theory analysis, qualitative and quantitative research (questionnaires), statistical analysis (questionnaires and reports) and content analysis (selected papers; radio/TV stations; web pages). Surveys were carried out in: 2002, 2006, 2010, 2014 and 2018. The survey was followed at the region of Lower Silesia. In this paper there is presented detailed data from the study of Dzierżoniów county. There were chosen varied types of communes: periphery and centre of the region. The group of around 2500 respondents was analysed.
\end{abstract}

Keywords: local community, local elections, local media, communication management, political marketing

\section{Introduction}

The way people connect and communicate in their local communities has transformed in recent years due to increasing use of social media platforms, the Internet and digital communication devices. A key feature of the new communication technologies and platforms is their interactive nature. In other words, they are not only a medium of information, but also offer a forum for discussion and debate among people and/or organisations. Several studies have shown that the Internet increases

1 The research was followed due to the MSCA Horizon 2020 funds. 
the number of social contacts and relationships because it generally enhances the opportunities for interaction. It has also been shown that the use of online platforms can potentially increase and supplement civic involvement. Räsänen and Kouvo, for example, found that there is significant relationship between Internet use and sociability and that online use is a predictor of civic engagement (Räsänen and Kouvo, 2007). The importance of online platforms in public communication has also been emphasised in EU policy documents. Enhancing the relationship between citizens is often cited as a goal for digital government and new tools such as social media have the potential to improve interactions through dialogue and greater transparency. Hence, the Internet, in its broader sense, has significant implications for local democracy. It is debated, however, whether online platforms, such as social media, improve the democratic processes or not. This aspect is clearly seen in all cases of political communication. The most significant period for local public sphere elicitation is the local election campaign. As is often the case with the introduction of a new media form, the debate becomes polarized with some emphasising the opportunities while others the challenges of public dialogue and local community engagement.

\section{Theoretical Approach Communication Management in Political Marketing}

Marketing activities are pursued all the time, but they are intensified during the elections campaign. Marketing actions taken in this time have even a specific name - election marketing. Its aim is to popularize the candidates and the party's political program, gain the highest amount of votes by the candidates and, in consequence - win the elections or achieve the best result possible. The concept of political marketing refers to the way in which the techniques of marketing are applied to politics and thus to the category of political communication. According to Ringold and Weitz the basics of these marketing techniques are the same, they may vary somewhat according to the task they are applied to. They confirm that political marketing is a specific process of delivering value to the customer which based on the classical market structure as selling and buying goods (Ringold and Weitz, 2007). Kotler and Keller (2006) added that, marketing is the art and science of choosing target markets, getting, and holding on to customers by delivering superior value. Beckman (2018) suggests that election marketing is due to provide important benefits to the target groups or in this case the voters and is based on classical marketing tools (e.g.: paid advertising, direct mail, publicity techniques, celebrity endorsements, online campaigning, segmentation, microtargeting).

Therefore, political marketing is not a supplement to politics or an effective and expensive setting for political activities, it is the ability to use the natural resources 
of the party in an effective and suitable way depending on the situation. Political marketing can be defined as the application of marketing principles and procedures in voting campaigns by various individuals and organizations. The procedures involved include the analysis, development, execution, and management of strategic campaigns by candidates, parties, governments, lobbyists and interest groups that seek to drive public opinion, advance their own ideologies, win elections, and pass legislation and referenda in response to the needs and wants of selected people and groups in a society (Newman, 1999). Activities in the field of political marketing start with the change in the way of thinking about a politician, and then they concentrate on gaining support for their actions in particular public space. The politician and the party are treated, in accordance with the philosophy of political marketing, as products, which have to sell high and there is no better way to promote the product as through media so nowadays media seems to be the main actor at the "political market arena" which seems positive from the contemporary public opinion perspective. Mass media play a unique role in transmitting information to voters and in shaping their political attitudes through precisely designed marketing strategies.

The main aim of political marketing is to increase the support for a political party or a politician. Marketing activities are targeted both, at voters and the media, which not only transmit, but also reinforce and process information. Therefore, the role of the media in political marketing is slightly different to their role in business marketing. A political party is the counterpart of the producer, but does not have at its disposal a commercial network, a shop shelf where a product can be put to be found by a consumer. The "product" of the political party - a politician or a political project - is available for the overwhelming majority of the voters through the media. The main data carrier on the way from a politician to a voter - a counterpart of the commercial network - are the media.

Researchers used the market analysis standards to classify different activities of election communication management. They propose the following distinction: 1) the product-oriented parties management; 2) sales-oriented parties management; 3) market-oriented parties management (Shama, 1976; Newman, 1994; LeesMarshment, 2001ab; Henneberg, 2002). Based on a merger of political science and marketing, political marketing theory holds that product-oriented parties or campaigns tend to focus on the core of the political product - the ideology and policy positions as formed through internal processes and deliberations. A product-oriented party could thus be described as policy-seeking.

Strömbäck admits that the sales-oriented party is similar to a product-oriented party in the sense that the ideology and policy positions are formed in internal processes. In contrast to product-oriented parties, however, it makes use of market intelligence and marketing techniques for studying and segmenting the electorate, for message design, and for the selling of the party. Sales-oriented parties thus focus much more on election campaigning and campaign communication 
than product-oriented parties. While both product- and sales-oriented parties can be described as policy-seeking, sales-oriented parties are more vote-seeking than product-oriented parties (Strömbäck, 2010).

Lees-Marshment and Strömbäck confirms that neither party would however change the policies to appeal to voters. This is in contrast to market-oriented parties that use market intelligence not only to design the message and to develop and execute as effective campaigns as possible, but also to design the product and communication policies per se. If sales-oriented parties try to make people want what they offers, market-oriented parties try to offer what people want. Market-oriented parties should be understood as the least policy-seeking, and the most vote- or office-seeking, party type (Lees-Marshment, 2001ab; Strömbäck, 2010).

According to mentioned marketing strategy based on running information campaign during the voting time it must be highlighted that new standards of digital era have also changed the way of managing the $21^{\text {st }}$ century political marketing as a whole. The Web 2.0 technologies provide web experience from the buzz marketing, that representing their engagement in information sharing. It is not limited to only readers of the content prepared by the site owners, but also, active contentgenerators to share their personal experiences, provide feedback, and express their sentiments in positive, negative or neutral (Luo et al., 2016). Thomas (2004) defines "Buzz Marketing as the amplification of initial marketing efforts by third parties through their passive or active influence". According to (Luo et al., 2016), consumer buzz is user generated word of mouth message that is review of product or services that are voluntarily posted on a website by consumers about their experiences with the product.

Digital media Buzz is a term used in viral marketing and this can be defined as the interaction of people on digital networking sites about product or service or an idea which amplifies or alters the unique marketing message. This emotion, excitement, energy, or anticipation about a product, service or an idea can be positive or negative.

The virtual public sphere is very important and useful for all public sector but especially for business which shifts most of marketing activities from the real space into the digital one (Štefko et al., 2011). According to Eyrich, Padman, and Sweetser (2008), industries are using social media for maintaining a public relationship. Even the non-profit organizations are also adopting social media for maintaining their public relation (Curtis et al., 2010). Higher education institutions are using social media for teaching, learning and sharing (Zelick, 2013). Social media is a hybrid element of promotion mix (Mangold and Faulds, 2009). Taylor (2010; 2014), suggested that social media tactics should consider in public relation strategy. The use of digital media is not only limited to corporate houses to maintain their public relations, but also the component of social media evolved as an important tool for advertisement in the election and has become a potent platform for expressing opinion worldwide, for example 2008 Obama’s Presidential elections (Smith, 2009), 
New Zealand general election (Cameron et al., 2016), Korean elections (Kim, 2015), and in Swedish election (Larsson and Moe, 2012).

\section{Research Description Methodology and empirical background}

The paper is going to be an analysis of communication management standards which were designed for local elections campaigns in Poland in 2002, 2006, 2010, 2014, 2018. The 2002 was chosen as the starting point of the analysis because of the following facts: 1) those were the first direct local elections for mayors/municipality heads; 2) the number of council members was reduced by law all of which heralded an interesting competition. The high turnover rate of candidates for councillors across different regions of Poland in 2002, 2006, 2010, 2014 and 2018 local government elections has been attributed in part to the volatility caused by greater media and public interest in council issues. Aims of the research were as follows: 1) to check which medium is the most popular and effective source of information for local public debate; 2) to assess the standard of information management during the local elections; 3 ) to analyse the strategy of political communication management and public opinion activity. Presented paper examines the impact of local media change for voters in Poland before the local elections time. The author focuses on: selected aspects of electoral behaviour management; media usage; media coverage; communication management; electoral management. The paper is based on the qualitative and quantitative research (questionnaires), statistical analysis (questionnaires and reports) and content analysis (selected papers; radio/TV stations; web pages). Surveys were carried out in: 2002, 2006, 2010, 2014 and 2018 in region of Lower Silesia. There were chosen varied types of communes: periphery and centre. The group of around 2.500 respondents was analysed. They were asked such questions as for example: interests in political issues of the region; main sources of political information; the participation in the local elections; the impact of the media elections campaign. In this paper there is presented data from the study of Dzierżoniów county. The other sources were: 1 ) interviews with: journalists, editors, clerks, politicians - number of interviews 335; 2) statistics: GUS - Statistics Poland; PKW - Commission of National Elections; 3) secondary studies; 4) local media content.

Twenty years after the collapse of the communist system, the local landscape of Poland has radically changed. First of all because of the administration reform giving much more power and strength to the local authorities and changing the local elections rules. Secondly, due to free media which appeared just after the collapse of the communist rule. Polish media market has experienced tremendous changes since 1989. Privatization has been put Poland away from an ideological 
to a market-driven media model. This could lead to Polish media being dominated by corporate interests as media conglomerates gain a larger share of the media. But those changes also brought citizens new opportunities of information sources. Everybody can now choose from a wide variety of newspapers, glossy magazines, specialized journals and regional titles, many owned by foreign publishing houses that rushed into Poland after 1989. Local and superlocal media has also expanded at a rapid rate since 1989. Three periods of their transformation may be noted. The first was founded upon widespread support for "Solidarity". The second phase was rooted in the dissolution and disbanding of the anti-communist forces. Finally, local media is now based upon profit rather than political thought (BiernackaLigięza, 2014).

The comprehensive development of the media forces a new approach to government information policy. As pointed out by Piasecki (2003), the turn of the $20^{\text {th }}$ and $21^{\text {st }}$ centuries is crucial for local governments in Poland. During this period in most offices in cities/towns organizational units for promotion, information and spokesperson agencies were created. Their task was not only building up positive relationship with journalists but their responsibility was also the formation of media policy across government. It included the impact of such forms as for example: development of information services; preparing a calendar of events (thematic and general); co-editing regular columns in local newspapers; insertion of thematic insets in local newspapers; publishing sponsored articles; organizing information campaigns; publication of mayor's statements and appeals; publishing own newsletters, advertising brochures and guides. Moreover, almost every municipality had already been using developed system of communication with the commune society. Local governments have begun to look favourably on the editors who stared to visit editorial offices. They even were willing to take part in the initiative in dealing with the editorial staff, which resulted in increasing possibilities to influence the media created image of self-government. A positive effect of a change in approach to media representatives was increasing the number of local themes in the independent magazines, corresponding to the needs of readers. But we should keep in mind that cooperation between local government representatives and local elites did not always proceed peacefully (Biernacka-Ligięza, 2014).

Analysing both those political and communication changes in Poland at the beginning of the transformation period, Siemiński believes that:

In the face of still insufficient interest in local elections establishing cooperation by local authorities with majority of residents, tacit during elections, becomes more and more important. Since most of the residents do not participate in elections, authority elected by minority should meet this indifferent majority in order to reduce this indifference and encourage local residence to participate actively in the life of this community and this may possible only thanks to the properly managed information policy (Siemiński, 1999, p. 21).

Launched in the 1990s process of democratization of social and political life in Poland poses new challenges for local communities and, indirectly, for the local 
process of political communication, because the more the local community will be focused on matters of local policy, the greater its influence will be and ability to shape mechanisms of local development. It is also important from the point of public participation in exercising of public authority and control. There are presented detailed data from the last five elections campaigns for: Dzierżoniów county and commune compared with the general country turnout (see: Figures 1-5).

Moreover analysing the turnout in the Dzierżoniów county during the 2002, 2006, 2010, 2014 and $2018^{2}$ elections we can see slightly decreasing number of voters. It must be underlined that smaller towns (Niemcza; Pieszyce) and rural communes (Łagiewniki; Dzierżoniów commune) proved to be more integrated and engaged in the elections. The turnout over 50 per cent is rather impressive result for local elections in Poland. There were a few factors which influenced this result. The most important one was the growth of trust and improvement of the communication between the local government and the inhabitants and of course professional based on partnership and positive relations in the commune elections campaign. Respondents overwhelmingly indicated willingness to participate in local elections in 2006 (53\% the actual turnout was lower around 39\% in all next elections). Half of the respondents who are determined and undecided to participate in the forthcoming local elections are not sure yet whether they will vote for the same political organization as the last time. Stated turnout in local elections held in 2010 was around 39\%, and the result is like the actual voter turnout. Among the respondents from towns, is a large group of people who do not remember which political organization in past elections they gave vote to. The participation level of the next two elections rounds (2014 and 2018) stayed at approx. the same level (around 40-45\% in towns and $50-58 \%$ in smaller communes).

Considering factors which may influence the level of community participation in the public debate and elections it is worth looking at the standards and quality of communication techniques used by local politicians and establishment. In the survey residents made assessment of the municipal authorities for the period from the beginning of its term (2002-2006, 2006-2010, 2010-2014, 2014-2018). The effectiveness of local authorities' communication efforts according to the respondents was relatively high.

The results of the research "Local authorities communication skills 2002-2018"3 indicate that the rule of openness and helpfulness towards the inhabitants, adopted by council members, proved to be very successful - the assessment of the relationship between the inhabitants and authorities significantly increased (Figures 6-10). The problems of the region became most important and private interests ceased to play a significant role, this changed the negative image of the local parliament

2 Analysis of the results of previous local elections in Poland indicate show also quite similar turnout in the entire county: in 1990 the representatives of the municipalities were chosen only by $42 \%$ of those eligible to vote, in $1994-34 \%$; in $1998-45 \%$.

3 Author's own research. 
effectively. The number of expensive and spectacular endeavours was limited and the saved resources were spent on road and school repairs, social help, etc. Moreover, conclusions drawn from the survey proved that the new council members are aware of the important role played by information, effectively used the benefits of access to the media and published all information about their activities in local press/the Internet, gave interviews to the radio/TV or simply participated in meetings with inhabitants. However, it is worth noticing that, they did not promote their own image but the effects of their actions. In the press far more often appeared reports from meetings with investors in which the mayor participated, however more important than him was the company and its offer. Therefore, one can presume that this kind of promotion proved to be efficient because since the 2006 elections mayors voting committee has been successful, both in the town and the powiat, without pursuing an aggressive and intensive campaign like the previous one.

The analysis shows that the inability to reach out to voters and wrong selection of information is, without doubt, one of the most basic causes of lack of interest in local elections. The majority of Dzierżoniów powiat inhabitants that did not vote in the 2002 elections justified their decision by stating that there was not enough information, the content or the form of the communication was wrong - mostly too vulgar or too sophisticated. They also drew attention to the fact that this was only a struggle for power and nothing would change in the town anyway. In their opinion the issues important to the town were disregarded and the campaign was just a battle between the "new ones" and the "old ones". The same people, asked about their participation in the following elections said that they would vote because the council members "turned out to be good" and the mayor did not stop at "pre-elections promises and did what he promised". In the answer to the question: What made you take this decision? - the majority (64\%) admitted that they did not want "things to change for the worse".

Local political organizations among the key factors that are within the contractual range of over $50 \%{ }^{4}$ of responses, mentioned as many as 7 of the 12 factors. In the first place $100 \%$ of the respondents stated to up to two factors, i.e. a well-organized campaign and active operations in the period between elections. According to respondents, four additional factors have a huge impact on the electoral success $(68-72 \%)$. These are: the image of the political organization, socio-economic situation of the country, effective communication with residents, the image of the leader of a political organization. The final factor according to respondents is the activity of political organization on a national scale (av. 51-55\%). Interestingly, in this group were not included such factors as: the results of nationwide surveys, the realization of program objectives, electoral program, constructive opposition. These factors have gained most responses as those that are not so important in de-

4 Data presented in this part of the paper are the result of the survey carried out in Dzierżoniów before the local election campaign in 2002, 2006, 2010, 2014 and 2018. 
termining the success (69\%), only the electoral program achieved as much as $80 \%$ or $73 \%$ of responses in this group. It is worth noticing that those factors have not changed through years.

Local political actors 5 in the group of the most important factors that are within the agreed range of over $50 \%$ of responses, named as many as 3 of the 18 forms of communication. In the first place $100 \%$ of the respondents mentioned two most common forms of electoral communication, that is, leaflets, posters and last two campaigns $(2014 ; 2018)$ Social Media. Personal contact with voters was also popular form of communication (56\%) which local political organizations could use to provide information about the candidate/organization during the elections. Other forms of communication were attached increasingly less attention. Only relatively high percentage of votes (37\%) received: advertising in popular newspapers and festivities. The responses indicate that many of these forms of communication are used to an average extant. In this group, most responses (62\%) received a proposal for "a meeting with the candidate". Other suggestions have received only $38 \%$. Among them were inter alia: brochures and newsletters, online platforms (mainly Facebook and local portals), websites, phone calls to voters.

For younger respondents (aged 18-45) the most effective political communication platforms are all kinds of media channels mainly digital ones (since 2014 Facebook and during last 2018 elections the popularity of Instagram increased. More than $65 \%$ of respondents made such choice. All media outlets were chosen by the people who are very interested in politics and regularly try to keep track of everything that happens in the political life of the city/town (80\%). In second place (38\% of responses) were conversations with other people, mainly family and friends. This was more often choice of men (40\%) aged 60 years and over (46\%), having a basic education (44\%) and those who declare different political views, though more often the views of the centre-right (4\%) and conservative (5\%) and least by far left (2\%). This form of political communication more often was also chosen by people who are totally not interested in politics (43\%). Middle aged respondents (aged 45-65) indicated that still the first source of information on local issues by the respondents was still conversations with other people (47\%) and in the second place were traditional local media (42\%). In terms of total number of indications in relation to certain sources of information respondents frequently pointed contacts with friends, newspapers, local news portal, radio and television.

Analysing the media preferences of voters on the choice of sources of information about local politics/politicians, we see that most would like to learn about

5 In another survey question political actors were asked to indicate such forms of communication, which they think is the best way of conveying information about their candidates / political organization taking part in local elections. Respondents were also able to evaluate the proposed forms in a scale of 1 to 5 , where: the worst way of providing information; providing little information; providing information fairly well; providing information considerably well; the best way of providing information. 
the activities of political parties and groups operating in the region from the local media - mainly their digital channels of distribution (34\%). It is worth mentioning that since 2014 there has been a significant change in terms of using local media distribution platforms by voters. Respondents pointed digital local news service (32\%), local TV - mainly distributed through the web (17\%), radio - mainly distributed through the web (11\%) and local newspaper - mainly online content (13\%). Local press is followed by the regional press (8\%), regional radio (6\%) and television (4\%). Less, at about $2-4 \%$ of responses, obtained in turn: Polish-Nationwide television, national press, other sources. Self-government newspaper received least indications (1-2\%). It can be assumed that the respondents in their choice were guided by a sense of information role of the self-government press in view of local population and do not want it to be treated by any political organization as a carrier of propaganda.

Among the regular items placed in local newspapers, readers could always find those that are concerned with the local process of political communication. The activities of local political actors and national political events were presented in the vast majority in a neutral manner to the discussed topics. It should be noted that until 2014 in almost every issue of the Dzierżoniów Weekly there were such publications which attitude to the reported cases could be clearly seen as negative or positive. It constituted only a small percentage and could not rather be regarded as a symptom of bias newspaper. Their intensity could have been observed particularly during the disclosure of irregularities and the incomprehensible actions of municipal authorities.

Analysing the frequency of publication and elections posters placed in local newspapers since the beginning of the free local elections' campaigns, it should be noted that originally posted elections materials were similar. Their authors were more often candidates for parliament and president than to the government. All the materials were published in one colour (black) and most contained only the text and logos. The publications sized to $1 / 4$ of a page.

The changes occurred only during the local elections in 1998, when the possibility of the local press in the electoral process of communication were noticed. Sponsored articles, interviews with candidates, additional images/pictures, colour printing were introduced. Their size run up to $1 / 2$ page and sometimes even to one or two pages. During the following local elections in the years 2002/2006/2010/2014 local press was "flooded" with the elections' posters, taking the place of the previous elections articles. In terms of elections communication dominate elections information similar in a form to leaflets and posters. Using them, committees or individual candidates presented their campaign slogans, colour photos and program theses. More information transmitted through the articles were much less. Newspaper articles in the form of a conversation, interview or a full presentation of the program in the local elections appeared less frequently and often as the work of journalists rather than the candidates themselves. The year 2018 brought a change in terms 
of local public sphere mediatization side especially for Dzierżoniów commune as the local newspaper was in a very week position. It was transformed into free biweekly and the quality of journalism decreased a lot. The main arena for public debate before the election became Social Media (both local media and candidates profiles) and local information services platforms. The most successful one are: service Doba.pl (www.doba.pl) and platform of local TV Sudecka (www.tvsudecka.pl).

In the local radio and television political communication was concentrated on regular interviews with politicians, elections spots promotional materials and presentations. Since 2002 (introduction of direct elections of presidents/mayors/governors) radio and TV debates were broadcast. However, they did not meet with too much interest from the audience. Voters often choose local TV "Sudecka" or local radio "Sudety". The media landscape has changed since 2014 when radio "Sudety" was bought by one the leading Polish broadcasting company - Radio Zet. Since that time radio Sudety has transformed from local information channel and place for a debate into music station format with very limited amount of time for local information service. Due to that its role in creating local public sphere was minimised. Doba.pl and TV Sudecka became the main agora.

Residents as objective and rather objective, for the agreed 50\% level, take in their assessments sources of information about the activities of political parties and organizations active in Dzierżoniów, such as: regional TV; regional press; local press; regional and local radio; city web site (did not exceed 50\%, but was rated as more objective than subjective); family; acquaintances. In contrast, residents as subjective and rather subjective for the agreed 50\% level indicated the sources of information related rather to the author of provided political content or identified with any political organization, namely: local government newspaper; information magazines of political organizations; newsletters of political organizations; local web site of political organizations; meetings with representatives of local political organizations.

The mentioned sources of information have not exceeded the agreed $50 \%$ of negative assessments of objectivity and developed as far below it. Among the indications was also self-government newspaper, which in its assumptions should be the objective carrier of information about the work of government and important urban issues. Its low assessment of objectivity can be caused by many factors, including such as historical precedent, when the press was attributed the nature of state propaganda media. In order to capture the objective regularity of this phenomenon additional in-depth studies and expectations for the collection of local newspapers should be carried out.

Analysing low assessment of the content of information provided by the information magazines of political organizations, one can assume that there is limited access to such information materials. Similarly in the case of meetings with representatives of local political organizations. The impression may be that the respondents do not believe in the objectivity of information provided by them, and assume 
that this is a peculiar kind of propaganda. In both cases there is the most numerous percentages, as many as nearly $50 \%$, who have difficulties with assessing the objectivity of these sources. We should consider why this is so, what factors make it difficult to decide. For this purpose, in-depth interviews could also be done. Perhaps, it will turn out that politicians lost voters trust long time ago, since voters in their assessments remain very careful.

The role of local media as one of the channels of political communication is relatively strong. The data presented in the following chart show that $59 \%$ of consumers believe that the political messages contained in it are objective and rather objective. Objective assessment was given by almost $72 \%$ of the audience declaring secondary education and almost 56\% declaring higher education. Only less than $21 \%$ assessed them as rather biased and not objective. Less than $19 \%$ of recipients had difficulty in making a firm assessment of the objectivity of the political content.

In assessing the political style of the content published in the media respondents define them as rather subdued (37\%) and subdued (24\%). Style content as more aggressive rate $17 \%$ of the audience, as aggressive only $8 \%$ the highest percentage of such indications - 19\% was in the group with higher education. Only $7 \%$ of the recipients have indicated "none of the above" while $23 \%$ and $25 \%$ "do not know". Local media were given positive assessment by the receivers. Most of them believe that the political messages contained in them are rather objective and in terms of style rather subdued. It has not been changed through years.

One of the important information provided by the surveys, was the level of interest in political, urban and national affairs showed by inhabitants. Respondents were asked to indicate only one response. The response rate for the interest in political affairs of the city are listed further on. Answers show little interest in political affairs. Not interested and rather not interested in local politics are about $79 \%$ of respondents. For matters of national interest the response rate showing lack of interest is about $58 \%$. Interest in only some of important political matters in the urban scale was expressed by $44 \%$ of respondents and in the national scale by $37 \%$. Awareness and interest in local politics at the level of general information reported by $24 \%$ of respondents, and at the national level almost $35 \%$.

Overall assessment of knowledge of political parties and groups acting locally is low (less than 22\%). The best known is the activity of local electoral committees and the least national parties: Platforma Obywatelska (Civic Platform), Prawo i Sprawiedliwość (Law and Justice), Sojusz Lewicy Demokratycznej (Democratic Left Alliance). It occurs that the low level of awareness is caused by a lack of local actions of individual politicians. This confirms the thesis that the parties and groups become more active only in the period preceding local elections.

Research results confirm constantly and systematically growing number of information related to the local government campaign. This may prove, on the one hand, the growing demand of local communities for political information at the self-government level, and thus directly related to them, and, on the other hand, 
the development of digital tools in the local public sphere. The latter conclusion is also confirmed by changes in the structure and functionality of analysed local information portals. In 2014, all of them had separate services dedicated to local government elections, where in one place users could find among others current news related to election issues, get acquainted with the profiles of candidates and ask a question directly to a specific candidate/group (replies were published on portals). The offer of portals is constantly improved and adjusted to the growing expectations of recipients.

Development of micro-regional portals is also evidenced by an increase in the number of publications aimed to activate recipients or arouse their interest in electoral issues, as well as an increase in activation activities initiated by portals. This increase in the number of initiatives activating recipients on portals is probably related to a few factors. Firstly it must be underlined the development of functionalities available on individual portals (e.g. separate websites devoted to electoral issues and the resulting other functionalities, such as on-line election forums with candidates). Secondly we can clearly see growing interest in electoral issues among the society (according to CBOS survey in 2006, 53-57\% of citizens declared interest in these issues while in 2014 it was 62-66\% and in 2018 already 64-69\%) (CBOS, Report nr 86/2018). Thirdly we can observe an increasing number of Internet users, for whom the Internet becomes more often the first source of local information, which in consequence leads to an increase in the popularity of local, micro-region$\mathrm{al}$ and regional portals. Fourthly the last decade shows more frequent use of the Internet in election campaigns at all levels of elections. For example, during the 2010 elections, it was not until the end of October that the first candidates registered at Doba.pl and started answering questions from Internet users; four years later, almost immediately after such a possibility was made available, they opened their accounts on services to present themselves to voters-internet users. Nowadays, the election campaign, including the local government campaign, takes place much more often in the virtual world; candidates participate in social media, create their own websites, etc.

It should be emphasized that possibilities of the Internet as a tool for mobilizing recipients are enormous. A fundamental change can be seen in the scope of portals' policy regarding information and usage publications. The conducted research indicates an increase in the intensity of publishing materials of this type since 2014. However, this may be due not so much to a change in the approach of individual portals, but rather to the fact that the last local government elections were conducted in accordance with the amended Electoral Code, which resulted in significant changes, e.g. the formula for electing councilors in single-mandate districts was introduced in all communes which are not towns with district rights, about which the portals wanted to inform voters-Internet users (Kornacka and Sikora, 2014).

In the analyzed cases, the efforts of journalists who wanted to maintain personal neutrality were noticed; they did not assess individual candidates or groups. This 
may be partly due to the specificity of relatively small communities, where the network of dependencies binding local media (and journalists working in them) exists at different levels (from personal, through economic to political). Also, in terms of raising controversial issues related to the course of campaign, it can be noted that the editors of portals are very reticent. Both during the 2010 campaign and in subsequent years, the discussed materials were a marginal phenomenon with no significant impact on the conduct of election campaigns.

Image 1. Parties profile in Social Media (statistics for leading parties in local elections 2014)

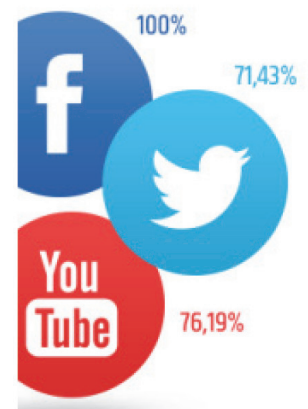

All 21 parties have their profile on Facebook 15 parties have their profile on Twitter 17 parties have their profile on YouTube

Source: Source: Report - Local Elections in Poland in 2014; Sotrender.

Image 2. Parties activitity on Facebook (number of engaged poiticians duruing the local elections 2014, 2018)

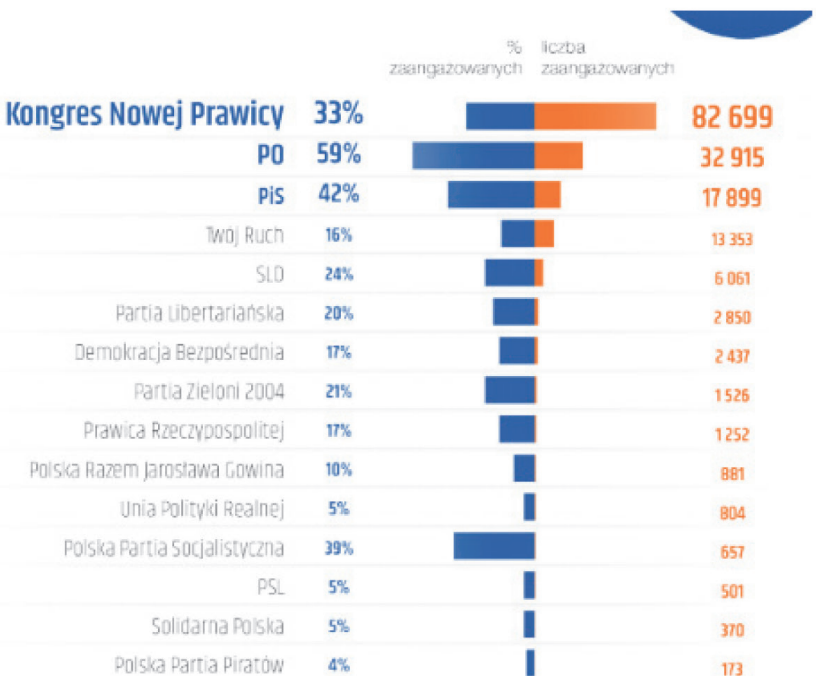

Politics - active users

Facebook trends Poland 2018 


\section{Polityka - Aktywni użytkownicy}

Facebook Trends Polska Listopad 2018

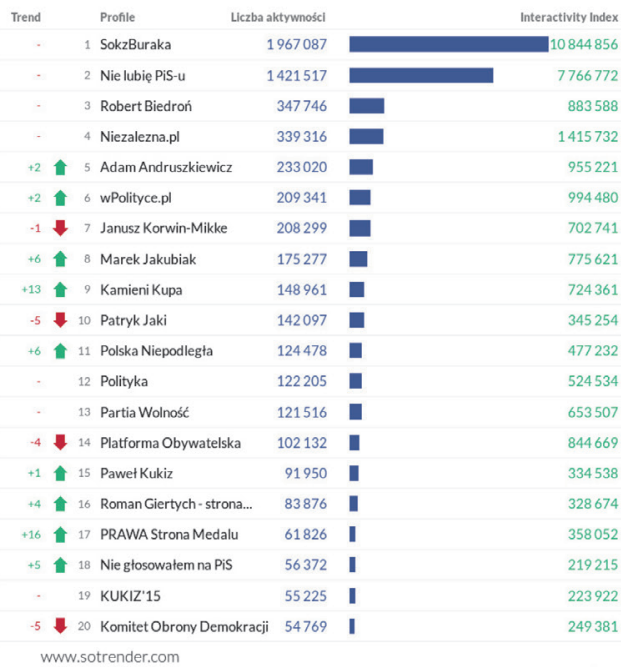

Politics - active users

Facebook trends Poland 2018

\section{Polityka - Fani}

Facebook Trends Polska Listopad 2018

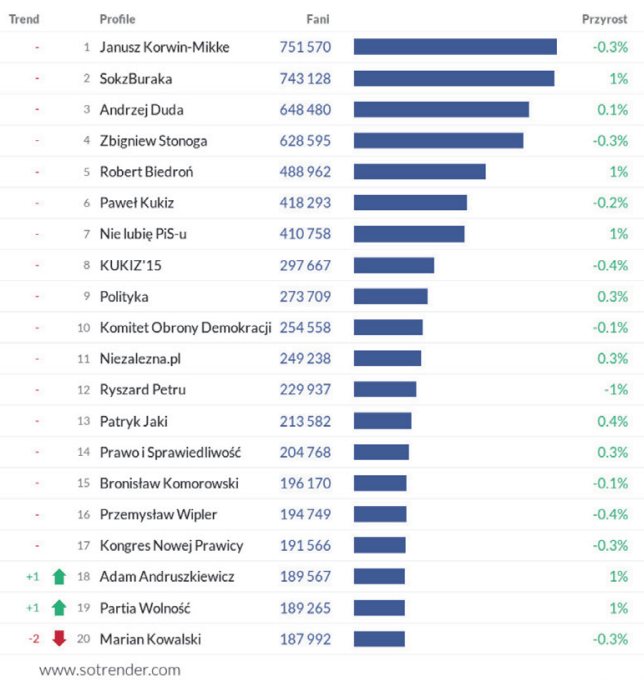

Source: Report - Local Elections in Poland in 2014; Sotrender 2014, 2018. 
Development of modern technologies significantly contributed to the professionalization of election campaigns that entered the cyberspace, adapting marketing communication instruments to new communication channels. Recognition of the Internet power in public space and the potential of social media in building relations with voters led local politicians to place significant emphasis on the campaign in this medium. Among the services most frequently used in election campaigns, it is worth mentioning Facebook, where the speed and range of impact and the process of users' identification with politicians has a significant impact on the actual election result. Data collected by Sotrender confirmed that Polish political parties consider Facebook to be the most important Internet communication platform. On Twitter, which generally attracts much more opinion leaders such as journalists and politicians, only 15 of the 21 parties surveyed had a profile. In turn, 17 parties were present on YouTube. However, in general, the use of the Internet in local government elections was still low. Judging by what was going on around them, the party staffs and candidates reached the voters with leaflets and posters in most cases. The Internet did not decide about the results of campaign, nor did it change the way Poles were involved in politics. It is surprising that local parties made little use of the opportunities offered by the Internet. Interviews with candidates at the local level showed that they often looked in the dark for their chances to appear on the web, but lacked the knowledge and skills to use digital tools. It may also be surprising that the individual committees did not conduct training or make simple strategies available to candidates for assemblies and councils. Besides, even if this happened, the effectiveness of campaigns conducted in the last $2-3$ weeks would not be high. The Internet, and especially social media, very much reward long-term, systematic activity, conducted not only immediately before the next elections. Local politicians treated social media more often as a tool of electoral communication or a place of self-presentation and not as a platform for public debate. Even the most active candidates did not make use of all the possibilities offered by the portal, limiting themselves to promoting their own image by publishing photos from events with their participation. Instead, they resigned from interactions with other users, including the possibility of discussion. This peculiar lack of dialogue can be explained by both "anxiety and lack of control over social media in politicians" (Baum, 2012, p. 171), but also fear of insulting others. It can also be a sign of lack of ability to choose the right argumentation techniques, which can result in disillusionment or even loss of support from the community. Political communication on Facebook in the period under review varied in terms of both quantity and quality. Moreover it must be underlined that small local committees are less visible in Social Media it is usually the privilege of the leading national parties. Considering small municipalities (fewer than 50.000) inhabitants where local politicians are recruited mainly from local committees we see rather limited engagement in SM. On the contrary in centres of the region (cities over 100.000) where the power is split between the leading national parties SM are the major tool 
for running political marketing. It must be also underlined that this is the result both of economic and social factors. Small municipalities and local committees have rather limited budget for promotion activities while budgets of leading parties and centres of the region are relatively high. Moreover in the periphery the relation between community members and their politician is rather close and the level of anonymity is not as high as in the centres.

The role of social media was therefore limited to juggling the emotions evoked by candidates in the platform users and to building a candidate's reputation based on published visual materials. These activities were characterized by information manipulation, which was particularly evident in the case of the candidate currently in power. Assuming the principle that "information is a powerful political weapon and its selective dissemination, restriction and/or distortion (...) is an important element in public opinion management" (McNair, 1999, p. 131), the candidates built their image and reputation, gaining the trust of voters. An advantageous reputation, which is an essential element of political capital, gives an increase in favour, attracting new followers.

\section{Conclusions}

It seems obvious that to more fully verify the hypothesis, further broaden in-depth empirical research is needed but due to the analysis which has already been followed a few general conclusions were formulated.

Firstly, voters draw information about the activities of political parties and groups operating in the city from various sources. According to the voters they are characterized by a diverse objectivity. Respondents were not able to identify one or a few major sources. Local press and regional television were indicated most frequently at the first three campaigns than it has turned into the digital platforms outlet. According to the sources of political messages, as objective and rather objective sources were chosen: nationwide television, regional television, national press, regional press, local press, nationwide radio, regional and local radio, websites, city, family and friends. Voters as a rather biased and not objective pointed to several sources of information that are related to the author of the content of political messages such as: self-government newspapers, political organizations magazines, political organizations newsletters, website of local political organizations, meetings with representatives of local political organizations. According to residents, the best media source to obtain information about the activities of political parties and groups is mainly the local press, local portals (mainly for small communities), regional press and regional television, rarely with regional and local radio and nationwide television, nationwide newspapers, and the worst source is the self-government press for which, as it seems, people keep more important function. 
Secondly, the interest in local political affairs on the part of respondents is rather small. Number of people who regularly try to keep track of political events is relatively small. They admit to be "more active public life participants" during the elections campaign when decisions about the future local government structure are being taken. According to the respondents in the group of the most important factors determining the success of the elections in the first place is the realization of program objectives, then the active operations in the period between elections, well-organized elections campaign, electoral program, effective communication with residents, the image of political organization and the image of the leader of a political organization. Of all the factors proposed to the respondents' formation of a new political organization just before the elections does not determine success. Almost half the population is interested in information about the programs of parties and organizations which set of candidates in local elections, and every tenth person looks for such information on purpose. Respondents among the forms of communication, which they think best communicate information about the candidates / political organizations taking part in local elections often pointed to the direct contacts by organizing meetings with candidates and personal contact with voters. About $1 / 3$ of analysed population also obtains information from advertisements in the media and through leaflets. Other forms of communication, were also evaluated relatively high.

Thirdly, when it comes to the assessment of the local government functioning in the period between the elections: 2002-2006, 2006-2010, 2010-2014 and 2014-2018 it seems rather positive for respondents. Evaluation of the "communication activity" of the local government representatives seems to prove the awareness of the communication power with special development of new technologies. ICT proved to be for majority of Polish communes mainly a tool for conveying information and providing services on the appropriate level, very rarely used as a platform for debate. However, local news sites are very popular - especially in smaller communes (often commercial initiative, or additional activity of local publishers/ broadcasters) and usually win with the press. Local politicians were not so often "visible" on the Internet, but it was not so easy to find information about local political parties, which additionally provide up-to-date information to their constituency. Poles are not looking for information about local politicians/politics on the Internet. It has changed since 2014.

Fourthly, there is a phenomenon in which organized political communication in the period between elections appears in lesser degree and relates mostly to political organizations acting only in the local area that do not have complex structures, nor the regional or national headquarters. These organizations are relatively more active during the elections period than other political organizations and are also rather independent of factors such as results of public opinion (e.g. SMG KRC). Strong elections support is obtained also by political parties which are local branches of nationwide party structures, not engaged in an organized way of 
political communication with voters. In the case of such parties as for example: Platforma Obywatelska (Civic Platform), Prawo i Sprawiedliwość (Law and Justice), Sojusz Lewicy Demokratycznej (Democratic Left Alliance) the electoral victory is frequently determined by the situation in the country and surveys results concerning electoral support.

Fifthly, the new communication technologies are each year more important and useful for the majority of Poles but still rather as the information and service not a debate platform. It can be noticed that important role in building local democracy and local identity is based on professionally run digital local information service, where readers can find both information and could participate in the debate. Local news sites are becoming more popular each day (often commercial initiative, or additional activity of local publishers/ broadcasters) and usually win with the press. The strengthen of the two-sided communication for building up the local debate seems to be an important issue for Polish politicians especially if the aforementioned "strong dimension of" democracy is to be further strengthened, consensus and cooperation need to be emphasized. The basis for the legitimacy is public debate, and the mandates of elected representatives are interactive or granted in consultation with those who are represented. The main role of the population is its opinion-forming ability and therefore, except information and services, the most important field of contribution in the usage of ICT should be debate. The biggest challenge will be to use the Internet to engage citizens in discussion about the future of the local government - in short - to strengthen political commitment and participation.

Lastly, a precisely planned marketing strategy and communication management - based both on the direct model and mass communication model seem to be the most influential factors for achieving final election success. The analysis of communication tools appointed during last two local elections campaigns (2014; 2018) proved that buzz marketing strategy which was adjusted to the digital media requirements - mainly social media platforms was very effective. Activities run by local committees in digital space brought expected results especially among the young audience. There is no doubts that digital space - especially the social media - became not only the most important source of information for local communities but also it appeared to be a modern local agora.

To sum up, the differences between digital media and press appear to be apparent. Websites are more cautious in expressing personal/partisan opinions and have less controversial content. At the same time, political preferences of Internet journalists are usually hidden, which often cannot be said about the local press, where a higher level of creating certain personal sympathies or antipathy was noticeable. Therefore, in case of the press, a high level of personalization of the message and a decrease in the importance of information content at the expense of its tabloidization can be seen. This indicates, despite some similarities, the existence 
of significant differences between Internet portals and the local press regarding behaviour of the media under discussion in the electoral situation in relation to its readers.

Therefore, based on research results, it can be concluded that web-based communication undergoes dynamic transformations in terms of website design and offered functionalities, and are increasingly making full use of the possibilities offered by the Internet in terms of mobilizing recipients. On the other hand, they are characterized by constant reticence in reporting controversial issues or unambiguous evaluation of events and people. However, the research results show how dynamically the range of functions performed by micro-regional web portals is changing, which indicates the existence of different types of media approach to the situation of political choices at the local level. Thus, there is no single, dominant type of portals activity in relation to the situation of elections during the next local government elections.

\section{References}

Baum M.A. (2012). "Preaching to the choir or converting the flock. Presidential communication strategies in the Age of Three Medias". In: R.L. Fox, J.M. Ramos (eds.), iPolitics: Citizens, Elections and Governing. Cambridge: Cambridge University Press.

Beckman A. (2018). "Political Marketing and Intellectual Autonomy". The Journal of Political Philosophy, Vol. 26(1), pp. 24-26. DOI: https://doi.org/10.1111/jopp.12126.

Biernacka-Ligięza I. (2014). "New Media in the Process of Shaping Local Democracy - the Case of Poland". In: A.M.G. Solo (ed.), Political Campaigning in the Information Age (pp. 88-110). Hershey, PA: IGI Global.

Cameron M.P., Barrett P., Stewardson B. (2016). "Can Social Media Predict Election Results? Evidence from New Zealand”. Journal of Political Marketing, Vol. 15(4), pp. 416-432. DOI: https://doi.org/10.1080/15377857.2014.959690.

Curtis L., Netten A., Moriarty J. (2010). “The Expected Working Life of a Social Worker”. British Journal of Social Work, Vol. 40(5), pp. 1628-1643. DOI: https://doi.org/10.1093/bjsw/ bcp039.

Eyrich N., Padman M.L., Sweetser K.D. (2008). “PR Practitioners' Use of Social Media Tools and Communication Technology". Public Relations Review, Vol. 34, pp. 412-414.

Henneberg S.C.M. (2002). “Understanding political marketing”. In: N.J. O’Shaughnessy, S.C.M. Henneberg (eds.), The Idea of Political Marketing (pp. 93-170). Westport, CT: Praeger.

Kim E. (2015). "A Comparative Study on Social Media Use and Public Participation in Korea and the United States: Does Social Media Matter?". The Korean Journal of Policy Studies, Vol. 30(1), pp. 207-230.

Kornacka M., Sikora K. (2014). “Wyborczy (nie)profesjonalizm”. In: M. Marmola, J. Podgórska-Rykała, K. Stelmach (eds.), Vademecum Ślask. Wybory samorzadowe 2014 w województwie ślaskim (pp. 233-251). Katowice: Towarzystwo Inicjatyw Naukowych.

Kotler P., Keller K. (2006). Marketing Management. Upper Saddle River: Prentice Hall.

Larsson A.O., Moe H. (2012). "Studying Political Microblogging: Twitter Users in the 2010 Swedish Election Campaign”. New Media and Society, Vol. 14(5), pp. 729-747. 
Lees-Marshment J. (2001a). Political Marketing and British Political Parties: The Party's Just Begun. Manchester: Manchester University Press. DOI: https://doi.org/10.1177/ 1461444811422894.

Lees-Marshment J. (2001b). “The Marriage of Politics and Marketing”. Political Studies, Vol. 49(4), pp. 692-713. DOI: 10.1111/1467-9248.00337.

Luo X.R., Zhang J., Marquis Ch. (2016). "Mobilization in the Internet Age: Internet Activism and Corporate Response". The Academy of Management Journal, Vol. 59(6), pp. 1-24. DOI: https://doi.org/10.5465/amj.2015.0693.

Mangold W.G., Faulds D.J. (2009). "Social Media: The New Hybrid Element of the Promotion Mix”. Business Horizons, Vol. 52(4), pp. 357-365. DOI: https://doi.org/10.1016/j.bushor.2009.03.002.

McNair B. (1999). An Introduction to Political Communication. London: Routledge.

Newman B.I. (1994). The Marketing of the President: Political Marketing as Campaign Strategy. Thousand Oaks, CA: Sage Publications.

Newman B.I. (1999). The Mass Marketing of Politics: Democracy in An Age of Manufactured Images. Thousand Oaks, CA: Sage Publications.

Piasecki A.K. (2003). "Samorząd terytorialny a media lokalne (1990-2002). Próba syntezy”. Zeszyty Prasoznawcze, Vol. 1(2), pp. 141-155.

Räsänen P., Kouvo A. (2007). "Linked or Divided by the Web? Internet and Sociability in Four European Countries”. Information, Communication \& Society, Vol. 2(10), pp. 219-241.

Ringold D., Weitz B. (2007). “The American Marketing Association Definition of Marketing: Moving from Lagging to Leading Indicator”. Journal of Public Policy \& Marketing, Vol. 26(2), pp. 251-260.

Shama A. (1976). "The Marketing of Political Candidates". Journal of the Academy of Marketing Science, Vol. 4(4), pp. 764-777. DOI: https://doi.org/10.1177/009207037600400309.

Siemiński W. (1999). Współzarządzanie gminą. Rada i zarząd gminy we wspólnocie samorządowej. Warszawa-Zielona Góra: ZCO.

Smith A. (2009). The Internet's Role in Campaign 2008. Pew Research Center Report. Retrieved from: https://www.pewresearch.org/internet/2009/04/15/the-internets-role-incampaign-2008/.

Štefko R., Dorčák P., Pollák F. (2011). "Virtual Social Networks and their Utilization for Promotion". Polish Journal of Management Studies, Vol. 4(1), pp. 1-238.

Strömbäck J. (2010). "A framework for comparing political market-orientation”. In: J. Lees-Marshment, J. Strömbäck, Ch. Rudd (eds.), Global Political Marketing (pp. 16-33). London: Routledge.

Taylor M. (2010). "Public relations in the enactment of civil society". In: R.L. Heath (ed.), Handbook of Public Relations (pp. 5-12). Thousand Oaks, CA: Sage.

Taylor M., Kent M.L. (2014). "Dialogic Engagement: Clarifying Foundational Concepts”. Journal of Public Relations Research, Vol. 26(5), pp. 384-398.

Wybory Samorządowe 2018, Raport CBOS, nr 86/2018. Retrieved from: https://www.cbos.pl/ PL/publikacje/raporty.php (access: 7.05.2020).

Zelick S.A. (2013). "The Perception of Web 2.0 Technologies on Teaching and Learning in Higher Education: A Case Study". Creative Education, Vol. 4(7), pp. 53-93. 


\section{ANNEX}

Figure 1. Local elections 2002 - turnout ${ }^{6}$ (first and second round)

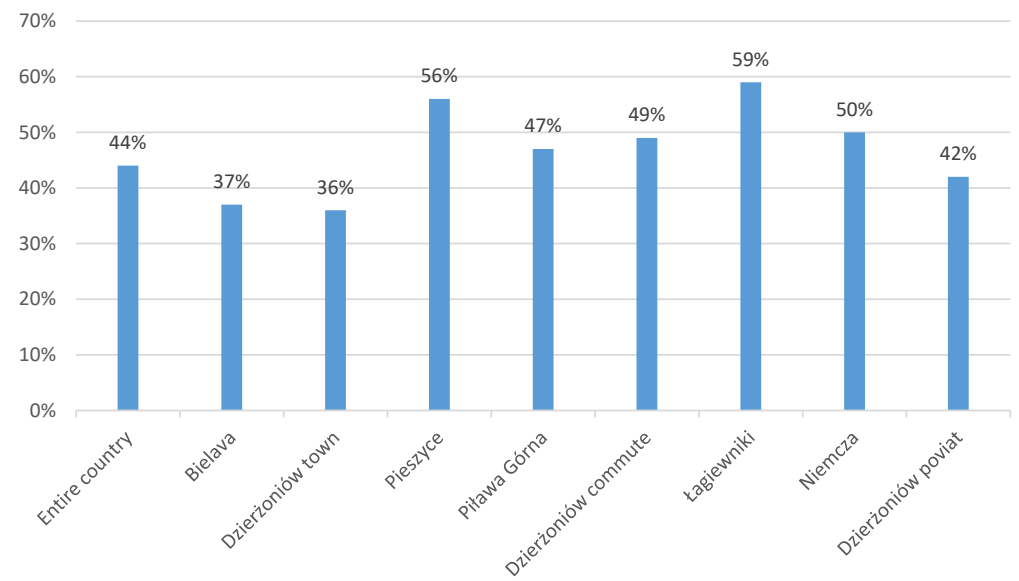

Source: Statistics of the Commission of National Elections, 2002.

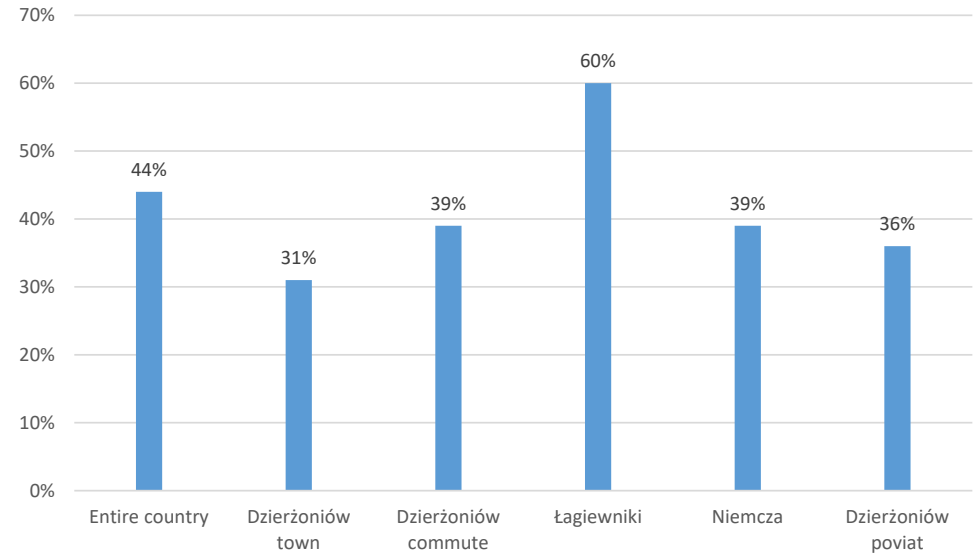

Source: Statistics of the Commission of National Elections, 2002.

${ }^{6}$ Data presented in the paper show the turnout of the first election round. 
Figure 2. Local elections $\mathbf{2 0 0 6}$ - turnout (first and second round)
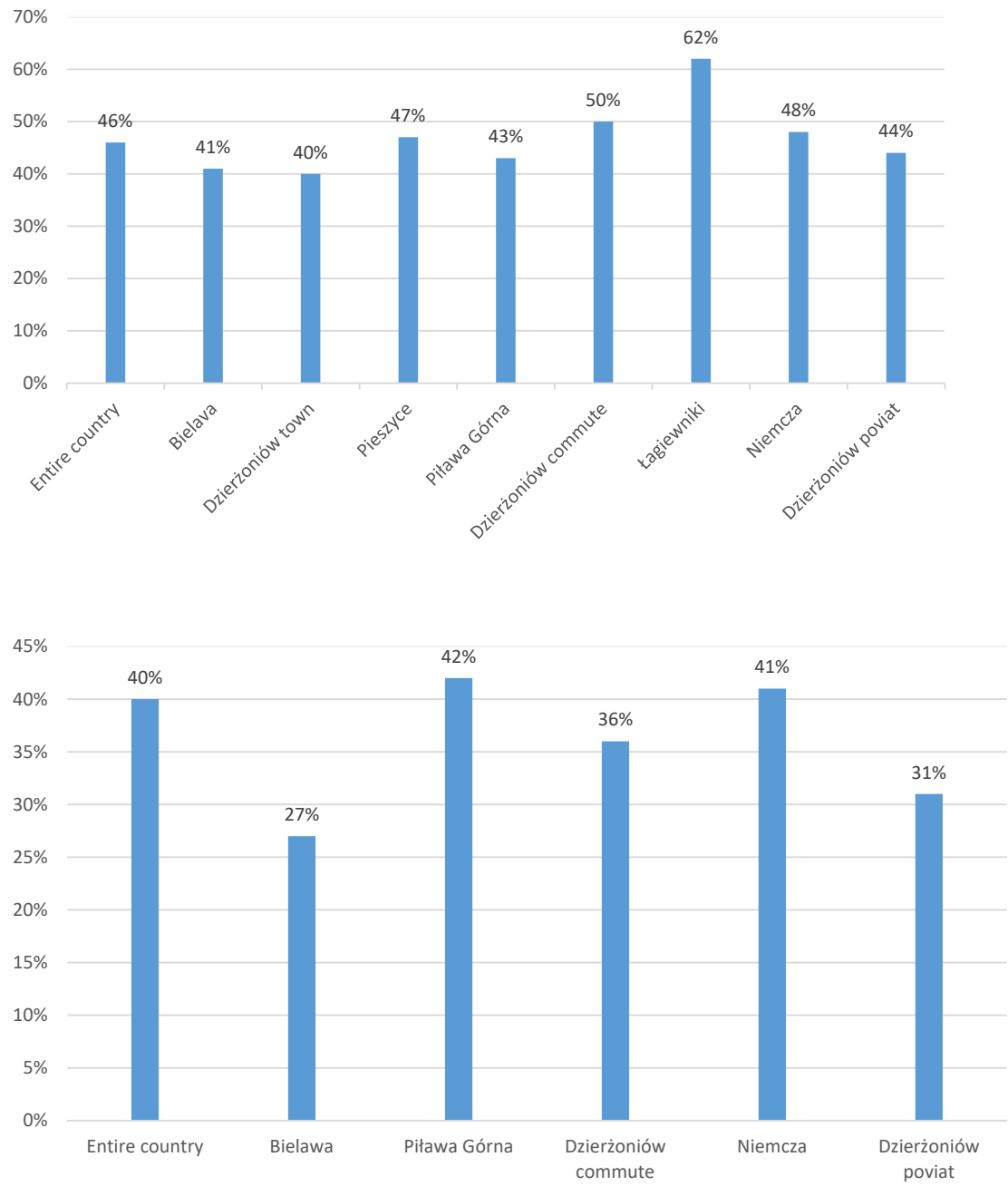

Source: Statistics of the Commission of National Elections, 2006. 
Figure 3. Local elections $\mathbf{2 0 1 0}$ - turnout (first and second round)
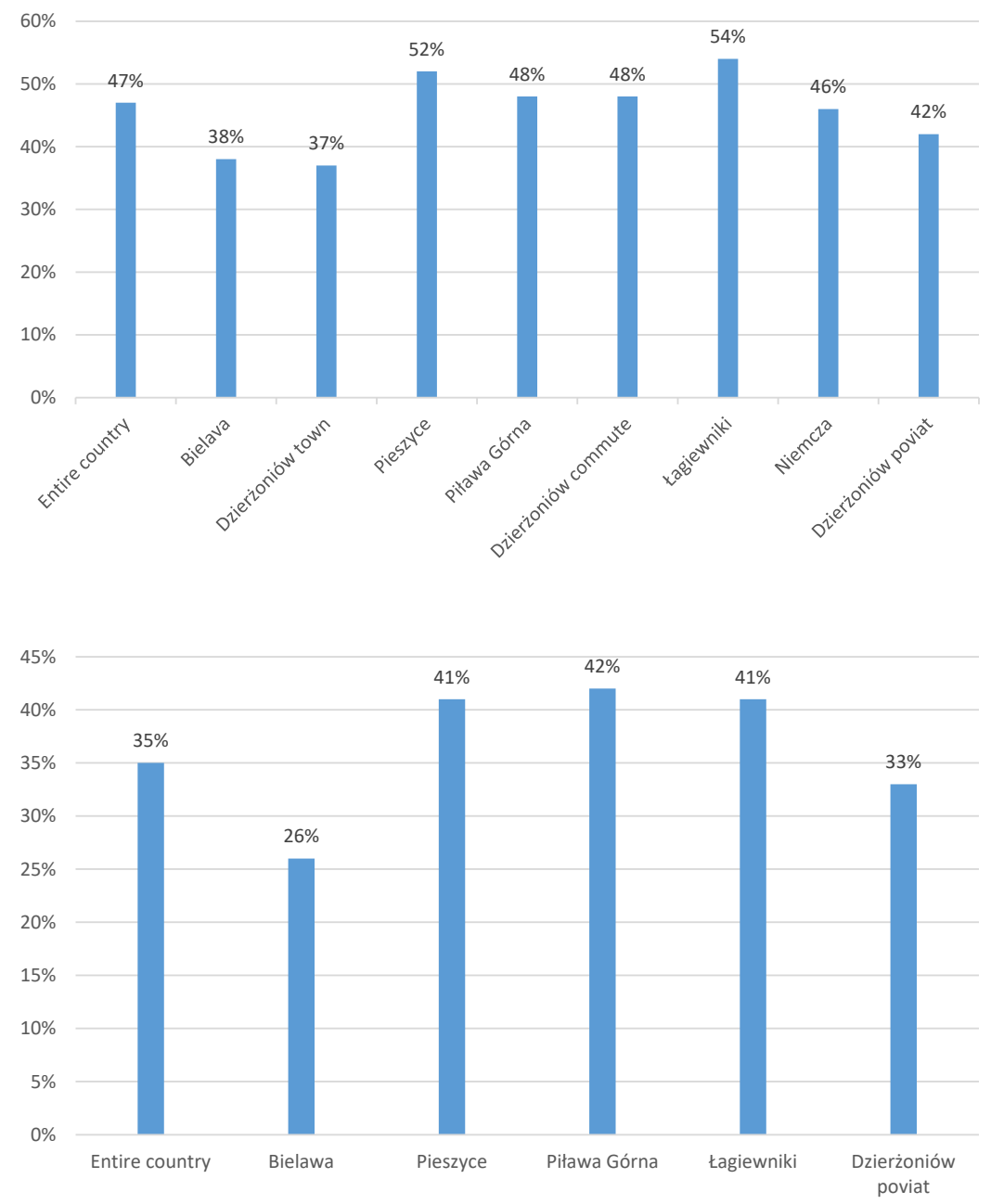

Source: Statistics of the Commission of National Elections, 2010. 
Figure 4. Local elections 2014 - turnout
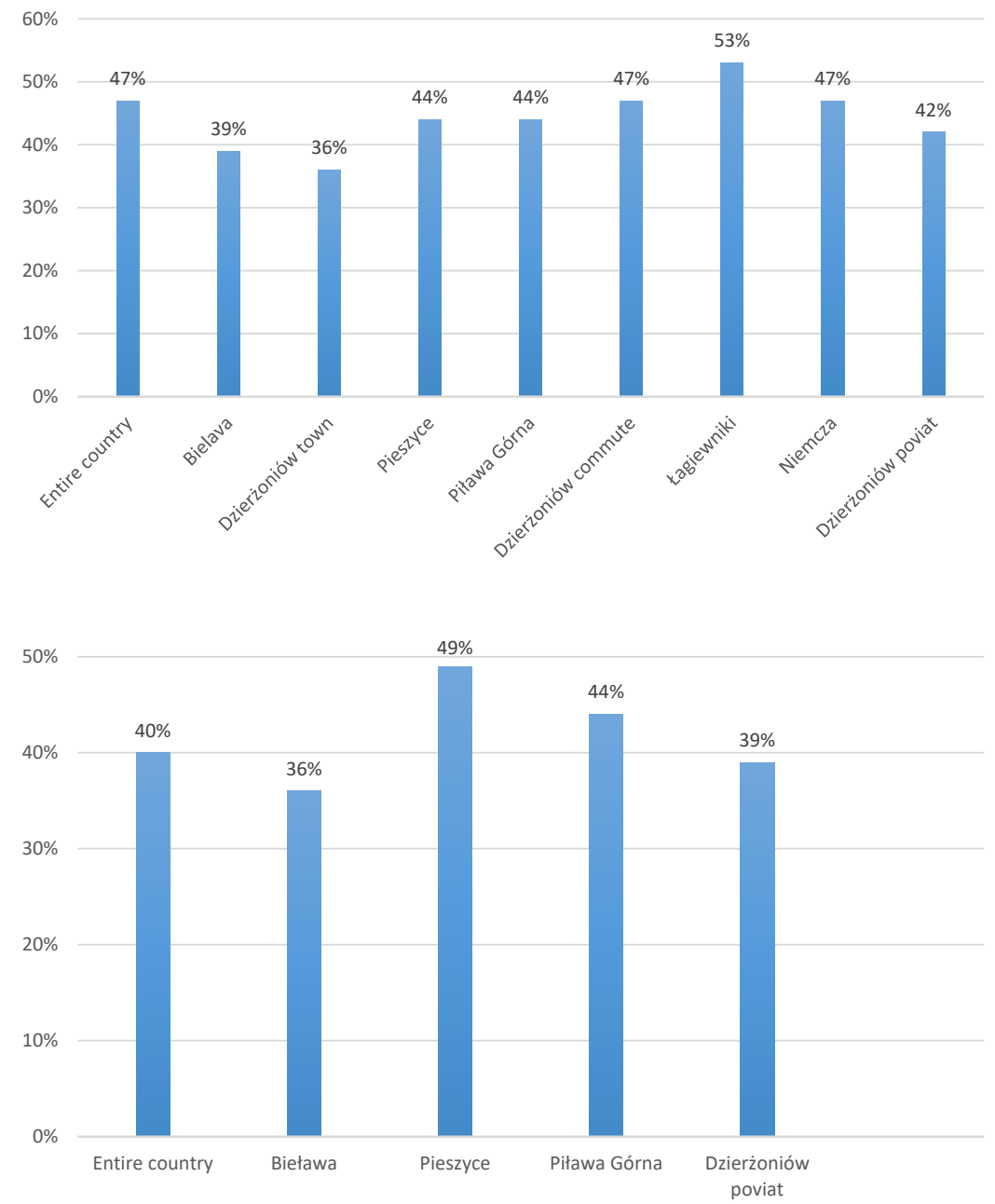

Source: Statistics of the Commission of National Elections, 2014. 
Figure 5. Local elections $\mathbf{2 0 1 8}$ - turnout (first and second round)
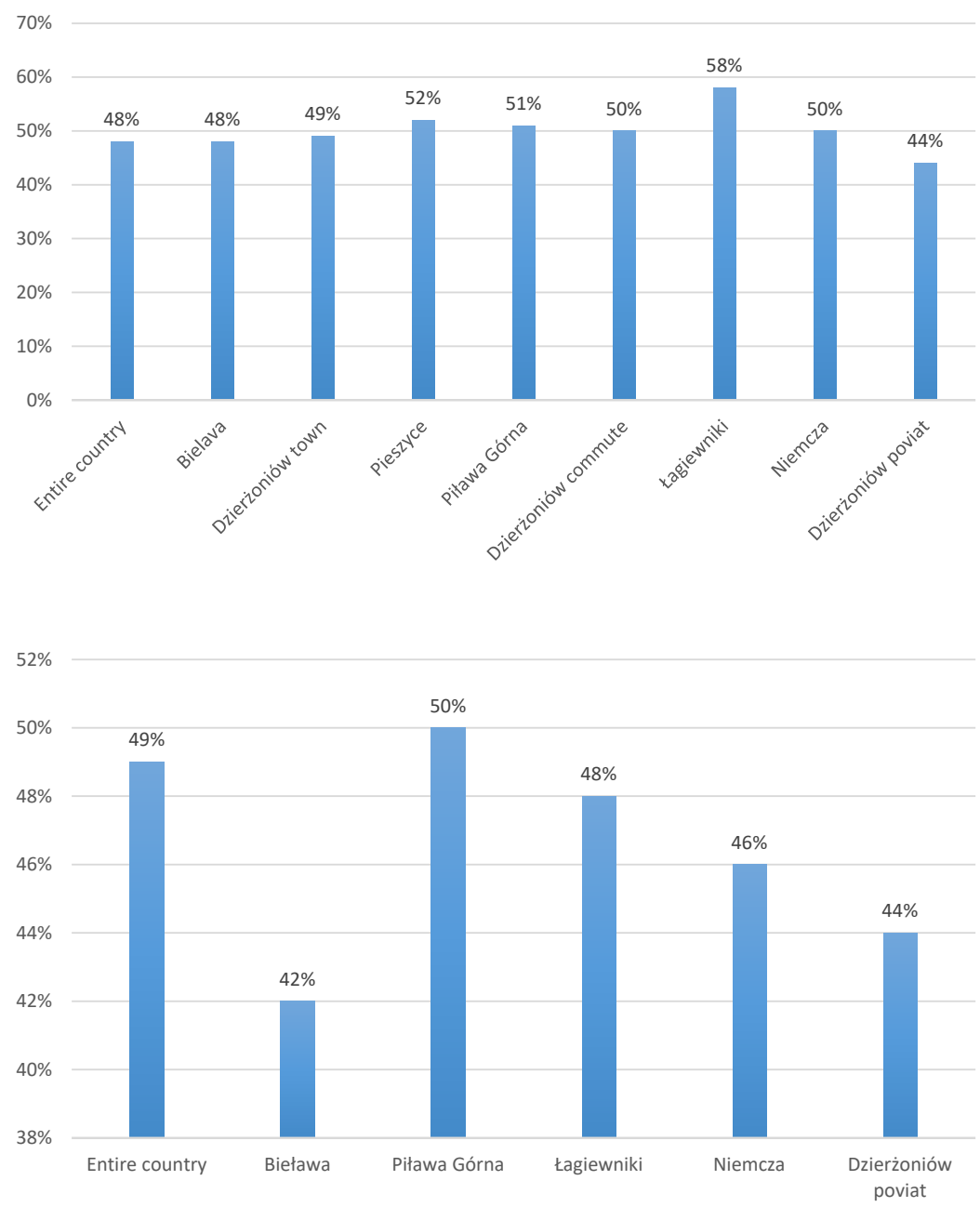

Source: Statistics of the Commission of National Elections, 2018. 
Figure 6. Local communication assessment (authorities) - Dzierżoniów case study 2002

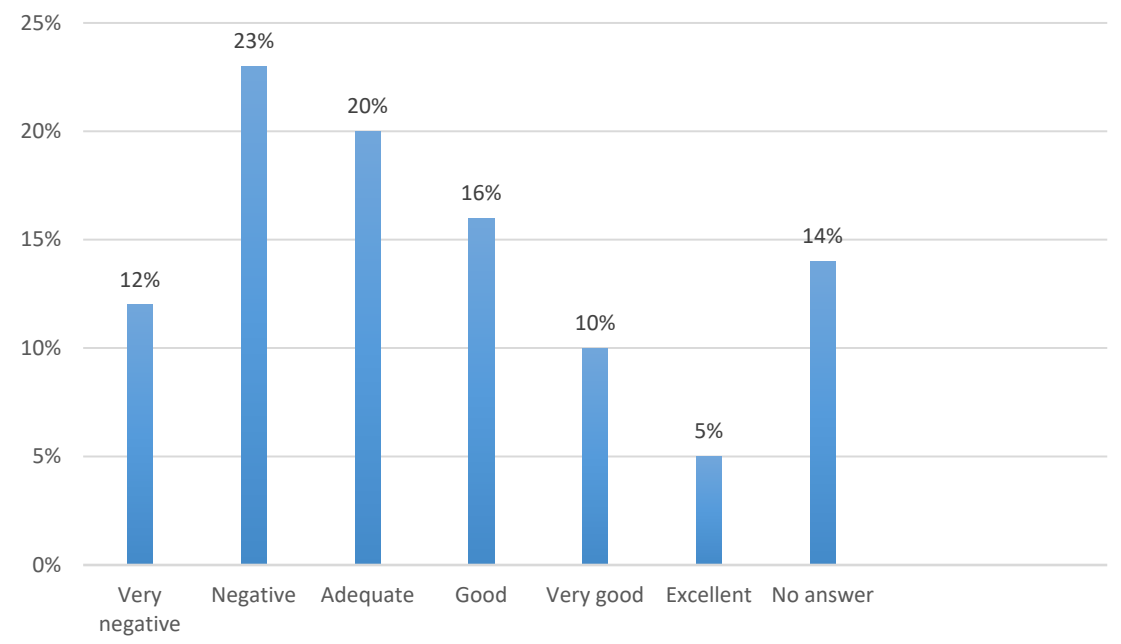

Source: own survey, 2002.

Figure 7. Local communication assessment (authorities) - Dzierżoniów case study 2006

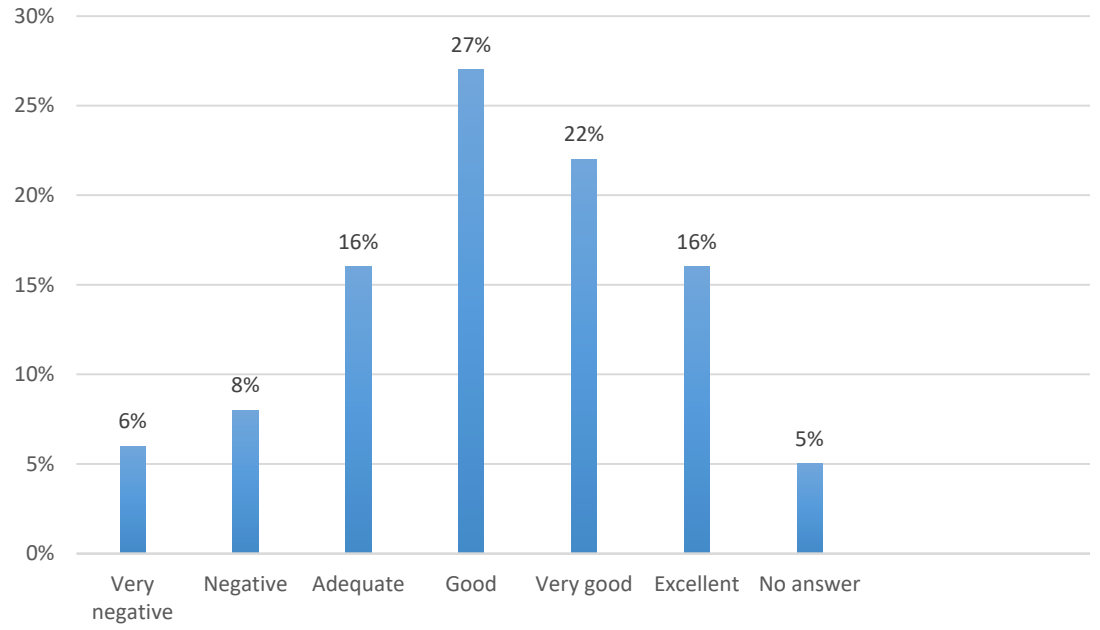

Source: own survey, 2006. 
Figure 8. Local communication assessment (authorities) - Dzierżoniów case study 2010

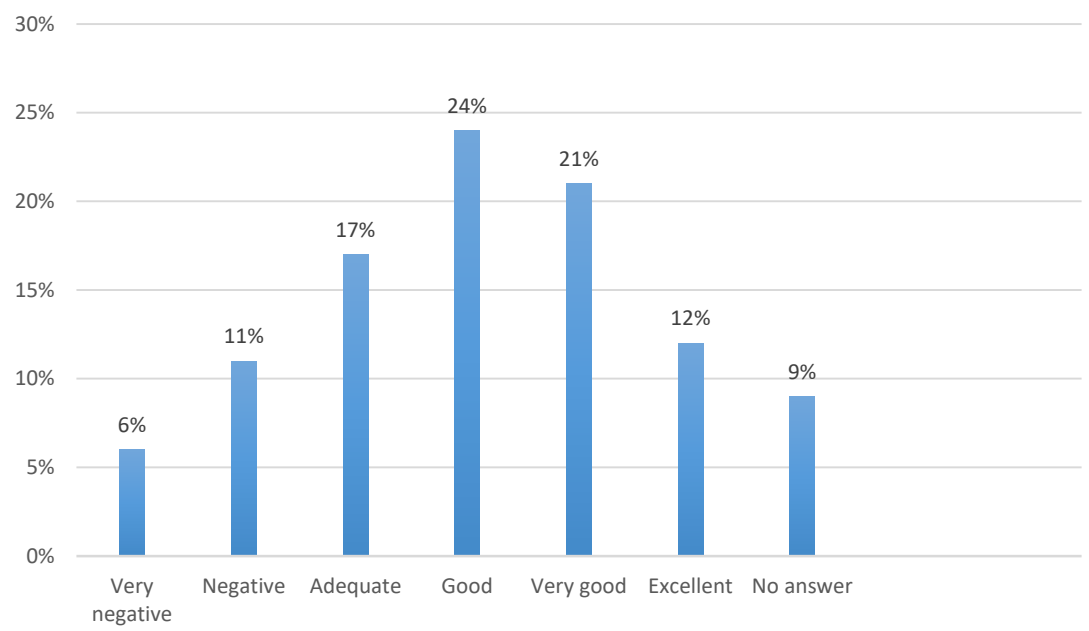

Source: own survey, 2010.

Figure 9. Local communication assessment (authorities) - Dzierżoniów case study 2014

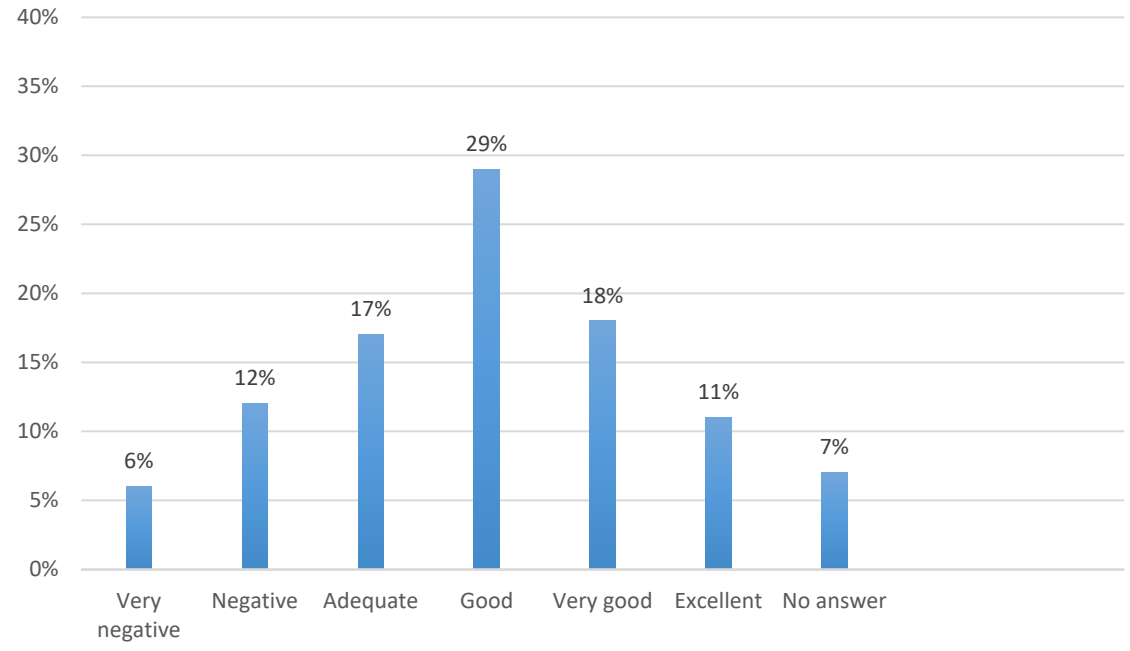

Source: own survey, 2014. 
Figure 10. Local communication assessment (authorities) - Dzierżoniów case study 2018

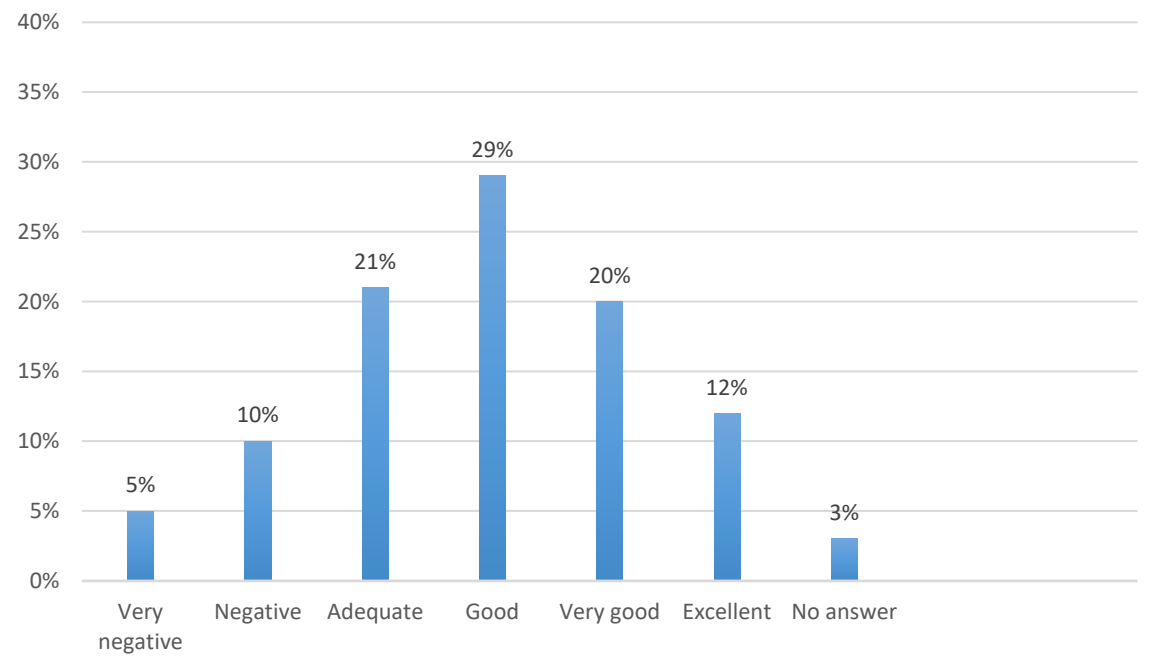

Source: own survey, 2018. 
